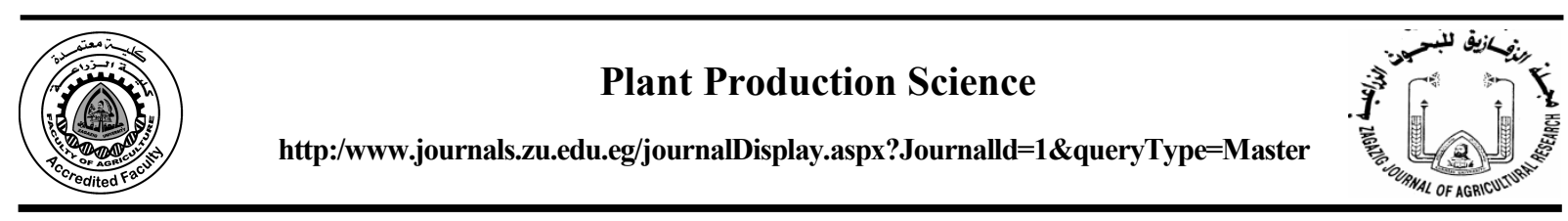

\title{
EFFECT OF SOWING DATE ON YIELD AND ITS COMPONENTS FOR SOME BREAD WHEAT GENOTYPES
}

\author{
Moamon A. Aglan ", E.A. Abd El-Hamid and A.M. Morsy \\ Wheat Res. Dept. Field Crops Res. Inst., ARC, Giza, Egypt
}

Received: 25/12/2019; Accepted: 08/01/2019

\begin{abstract}
Two field experiments were conducted at the experimental farm of Sakha Agricultural Research Station ARC, Kafr El-Sheikh, Egypt, during two winter successive seasons 2016/17 and 2017/18 to determine the effect of two planting dates (23 November and 23 December) on yield and its components of 14 bread wheat genotypes. The experimental design was randomize complete bloke with three replications. Each sowing date is sown in separated experiment, the first experiment was planted on 23 Nov.(recommended sowing date), while late one were on 23 Dec. in both seasons, Results indicdated that, heading and, maturity dates, grain filling period and rate, plant height, grain weight, number of grains $/ \mathrm{spike}$, number of spikes $/ \mathrm{m}^{2}$, grain and straw yields and harvest index were significantly affected by sowing dates. Recommended sowing date (23 Nov.) recorded the highest value for each of character in both growing seasons. Sids 4 and Line 10 were the earlier genotypes for days to heading and maturity. Misr 2 and Line 8 were the best genotypes for grain filling rate, grain and straw yield in both seasons. Whereas, Misr 2 recorded the highest value for each of plant height and No. of spikes $/ \mathrm{m}^{2}$. Line 7 recorded the highest value for each of grain weight and harvest index. For tolerance index (TOL), the lowest values were recorded for Lines 9, 11 and 10, respectively. With regard for yield reduction, the lowest values were obtained by Misr 2 and line 9 . Therefore, Misr 2 and line 9 recommended to sowing in both recommended and late sowing date in North Delta region.
\end{abstract}

Key words: Triticum aestivum, tolerance index, sowing dates, genotypes.

\section{INTRODUCTION}

Wheat (Triticum aestivum L.) the most important cereal crop in international commerce of the world. The total production of wheat in Egypt is still far below the consumption and annual demand. The local production is about $55 \%$ of the local requirement. This gap can be filled by increasing the planting area in the reclaimed lands, increasing the productivity for the planted area and decreasing the losses in production and consumption (Abd EL-Hamid 2006). The most factors that lead to increase wheat yield is breeding, producing new genotypes with high yielding ability, planting in recommended time and using all other ways such as fertilization, irrigation, weed control, pest control, the best storage and etc.

Sowing date is one of the most important agronomic factors involved in producing high yielding in small grain cereal crops, which

\footnotetext{
* Corresponding author: Tel. :+201015757521

E-mail address: Elsayedaliabdelhamid@gmail.com
}

affects the timing and duration of vegetative and reproductive stages. Several researchers (Nasim et al., 2006; Rahman et al., 2009; Ali et al., 2010; Alisial et al., 2010; Mostafa et al., 2010; El-Sarag and Ismaeil, 2015; Menshawey et al., 2015) studied the effect of planting date on wheat grain yield and its related variables which increased with normal sowing comparing to late sowing date. Higher grain yield in recommended sowing date was due to higher number of spikes $\mathrm{m}^{-2}$ and mean grain weight than late sowing. Abdel Nour and Hayam (2011) found that days to heading and maturity, plant height, number of spikes $\mathrm{m}^{-2}$, number of grains spike ${ }^{-1}$, 1000 -grain weight, biological yield and grain yield were significantly the highest in the recommended date compared to the late and early dates of planting.

The fluctuation in environmental conditions such as day length, temperature, humidity and precipitation may alter plant functions and productivity (Muhammad et al., 2013). 
In Egypt the grain yield was reduced under heat stress in late sowing, in the range of 30-46\% comparing with optimal sowing date (Abd ElShafi and Ageb, 1994). One among the strategies that farmers can use to stabilize and increase crop yields in the face of a changing climate is to adjust sowing dates. Singh and Uttam (1999) estimated yield loss as $39 \mathrm{~kg} / \mathrm{ha} /$ day for each day delay in sowing from recommended sowing date. Wajid et al. (2004) reported that recommended sowing on 10 Nov. gave higher grain yield over late sowing (10 Dec.) by $60.6 \%$.

The objectives of this study were to determine the effect of late sowing on the productivity of fourteen bread wheat genotypes, to determine the most suitable wheat cultivar for farmers in Kafr El-Sheikh Governorate and other surrounding areas with similar environmental conditions and to determine the losses in grain yield due to late sowing.

\section{MATERIALS AND METHODS}

Two field experiments were conducted at Sakha Agricultural Research Station, ARC, Egypt, during two winter growing successive seasons $2016 / 17$ and $2017 / 18$. The site is located at 30.94 North Latitude, 30.11 East Longitude with an elevation of about $6 \mathrm{~m}$ above sea level. Fourteen bread wheat genotypes (Table 1) were evaluated under recommended and late sowing dates. The first experiment was planted on 23 November (recommended sowing date), while late one was on 23 Dec., in both growing seasons. The experimental design was a randomize complete block with three replications. Each plot was consisted of 6 rows, $3.5 \mathrm{~m}$ length and $20 \mathrm{~cm}$ apart between them $\left(4.2 \mathrm{~m}^{2}=1 / 1000\right.$ faddan). Seeding rate was $60 \mathrm{~kg} /$ faddan . Monthly mean air temperature $\left(\mathrm{C}^{\circ}\right)$, and rainfall (mm/month) during the two growing seasons at the experimental site are shown in (Table 2). The growing degree dayes (GDD) were calaulated from mean daily temperature $\left(\mathrm{C}^{0}\right)$, and base temperature $\left(\mathrm{C}^{\circ}\right)$, as:

$$
\mathrm{GDD}=\frac{\mathrm{T}_{\text {max. }}+\mathrm{T}_{\text {min. }}}{2}-\mathrm{T}_{\text {base }}
$$

Where:

$\mathrm{T}_{\text {base }}=4.5^{\circ} \mathrm{C}$ in wheat (Parthasarathi and Jeuakumar, 2014).
Superphosphate $\left(15.5 / \mathrm{P}_{2} \mathrm{O}_{5}\right)$ was band placed at the time of sowing. Also, $\mathrm{N}$ fertilizer at level of $90 \mathrm{~kg}$ /faddan, was applied twice before the first and the second irrigations as ammonium nitrate $(33.5 \% \mathrm{~N})$. The other culture practicics where applied as recommended in the experimental area.

\section{Studied Characters}

Days to heading (DH), Days to maturity (DM), grain filling period (GFP), grain filling rate (GFR), plant height in $\mathrm{cm}(\mathrm{PH})$, number of spikes $/ \mathrm{m}^{2}$, number of grains/spike, 1000 grain weight $(\mathrm{g})$, grain yield $(\mathrm{ardab} / \mathrm{fad}$.$) straw yield$ (ton/fad.), harvest index (\%) (HI) (One ardab= $150 \mathrm{~kg}$ ).

The susceptibility index for grain yield was calculated using the following formulas:
1- Tolerance index (TOL) = YP-YS (Rosielle and Hambling, 1981).

2- Yield reduction ratio (Yr). $\mathrm{Yr}=1-\mathrm{YS} / \mathrm{Yp}$ (Gollestani and Assad, 1998).

Yield potential (YP) and stress yield (YS)

\section{Statistical Analysis}

Data collected in the two seasons were statistically analyzed according to the technique of analysis of variance (ANOVA) according to Gomez and Gomez (1984). The combined analysis was conducted for the two experiments in the two years. The recorded data were statistically analyzed using statistical software package Genstat version12. The least significant differences (LSD) at the level of 0.05 probability was employed to compare the differences among the treatment means according to Steel et al. (1997).

\section{RESULTS AND DISCUSSION}

\section{Analysis of Variance}

The analysis of variance for the collected data (Table 3) indicated that mean squares due to years, sowing dates, genotypes and all interaction combinations were significant or highly significant for all studied characters except for days to maturity, harvest index and interaction between years and sowing dates. These results indicated that all genotypes 
Table 1. Name and pedigree of 14 bread wheat (Triticum aestivum L.) genotypes used in the study*

\begin{tabular}{|c|c|c|}
\hline Genotype & Pedigree and selection history & Origin \\
\hline Sids 4 & MAYA “S”/MON “S”//CMH 74A. 2/3/Giza157*2 SD 10001-2SD-3SD-2SD-0SD. & Egypt \\
\hline Misr 2 & SKAUZ/BAN92 CMSS96M03611S-1M-010SY-010M-010SY-8M-0Y-0S) & Egypt \\
\hline Line 1 & SIDS 12 // WBLL1*2/BRAMBLING S. 16965 -018S -011S-1S -0S & Egypt \\
\hline Line 2 & WBLL1*2/BRAMBLING // HUBARA-21 S. 17017 -056S -019S-1S -0S & Egypt \\
\hline Line 3 & $\begin{array}{l}\text { GIZA 168/5/MAI "S"/PJ//ENU "S"/3/KITO/POTO.19//MO/JUP/4/K134 (60)/ } \\
\text { VEE/8/KAUZ/ATTILA /7/ KVZ /4/ CC / INIA /3/ CNO // ELGAU / SON 64 /5/ } \\
\text { SPARROW "S" / BROCHIS "S" /6/ BAYA "S" / IM S. 16959 -030S -010S-1S -0S } \\
\text { SHANDWEEL } 1 \text { /8/KAUZ / ATTILA /7/ KVZ /4/ CC / INIA /3/ CNO // ELGAU / }\end{array}$ & Egypt \\
\hline Line 4 & $\begin{array}{l}\text { SON } 64 \text { /5/ SPARROW "S" / BROCHIS "S" /6/ BAYA "S" / IMU S. 16969-030S- } \\
\text { 024S-1S-0S } \\
\text { CHEN/AEGILOPS SQUARROSDA (TAUS)//BCN/3/2*KAUZ/6/GIZA 168 /5/ }\end{array}$ & Egypt \\
\hline Line 5 & $\begin{array}{l}\text { MAI "S" / PJ // ENU "S" /3/ KITO / POTO. } 19 \text { // MO / JUP /4/ K } 134 \text { (60) / VEE } \\
\text { S. } 16862 \text {-035S -06S-3S-2S -0S }\end{array}$ & Egypt \\
\hline Line 6 & $\begin{array}{l}\text { MINO /6/ SAKHA 12 /5/ KVZ // CNO } 67 \text { / PJ } 62 \text { /3/ YD "S" / BLO "S" /4/ K } 134 \\
\text { (60) / VEE S. } 16869 \text {-010S -07S-1S-1S -0S }\end{array}$ & Egypt \\
\hline Line 7 & $\begin{array}{l}\text { MINO /6/ SAKHA 12 /5/ KVZ // CNO } 67 \text { / PJ } 62 \text { /3/ YD "S" / BLO "S" /4/ K } 134 \\
\text { (60) / VEE S. } 16869 \text {-010S -07S-1S-2S -0S }\end{array}$ & Egypt \\
\hline Line 8 & $\begin{array}{l}\text { MINO /6/ SAKHA 12/5/KVZ//CNO 67/PJ 62/3/YD "S"/BLO "S"/4/K } 134 \text { (60) / } \\
\text { VEE S. } 16869 \text {-010S -07S-4S-1S -0S } \\
\text { GIZA } 168 \text { /5/ MAI "S" / PJ // ENU "S" /3/ KITO / POTO. } 19 \text { // MO / JUP /4/ K }\end{array}$ & Egyp \\
\hline Line 9 & $\begin{array}{l}134 \text { (60) / VEE /8/ KAUZ / ATTILA /7/ KVZ /4/ CC / INIA /3/ CNO // ELGAU / } \\
\text { SON 64 /5/ SPARROW "S" / BROCHIS "S" /6/ BAYA "S" / IMU S. } 16959 \text {-030S- } \\
\text { 014S-1S -0S } \\
\text { GIZA 168/5/MAI "S"/PJ//ENU "S"/3/KITO/POTO. } 19 \text { // MO / JUP /4/ K } 134 \text { (60) }\end{array}$ & Egy \\
\hline Line 10 & $\begin{array}{l}\text { /VEE/8/KAUZ/ATTILA/7/KVZ/4/CC/INIA/3/CNO//ELGAU/SON64/5/SPARRO } \\
\text { W "S" / BROCHIS "S" /6/ BAYA "S" / IMU S. } 16959 \text {-030S-014S-2S -0S }\end{array}$ & Egypt \\
\hline Line 11 & GEMMEIZA 9 // ATTILA *2 / GIZA 168 S. 16947-08S-2S-5S-0S & Egypt \\
\hline Line 12 & GEMMEIZA 9 // ATTILA *2 / GIZA 168 S. 16947-08S-2S-7S-0S & Egypt \\
\hline
\end{tabular}

* Source: Wheat Research Department, ARC, Egypt

Table 2. Monthly mean air temperature $\left(\mathrm{C}^{0}\right)$, and rainfall $(\mathrm{mm} / \mathrm{month})$ during the growing seasons 2016/17 and 2017/18 at the experimental site

\begin{tabular}{|c|c|c|c|c|c|c|}
\hline \multirow[t]{3}{*}{ Month } & \multicolumn{4}{|c|}{ Temperature $\left(C^{0}\right)$} & \multicolumn{2}{|c|}{ Rainfall (mm) } \\
\hline & \multicolumn{2}{|c|}{$2016 / 17$} & \multicolumn{2}{|c|}{$2017 / 18$} & \multirow[b]{2}{*}{ 2016/17 } & \multirow[b]{2}{*}{$2017 / 18$} \\
\hline & *Max. & Min. & Max. & Min. & & \\
\hline Nov. & 24.9 & 17.9 & 27.65 & 23.01 & 0.0 & 0 \\
\hline Dec. & 19.3 & 10.8 & 21.50 & 18.40 & 32.94 & 0 \\
\hline Jan. & 18.2 & 5.7 & 18.85 & 14.03 & 9.6 & 36.4 \\
\hline Feb. & 19.7 & 10.2 & 21.53 & 14.50 & 25.2 & 16.6 \\
\hline Mar. & 21.7 & 17.9 & 25.51 & 16.59 & 0 & 0 \\
\hline Apr. & 26.5 & 21.6 & 27.80 & 19.94 & 10.6 & 0 \\
\hline Total & & & & & 78.34 & 53.0 \\
\hline
\end{tabular}

$*$ Max $=$ maximum, Min $=$ minimum 
Aglan, et al.

Table 3. Mean squares of all studied characters over the two seasons

\begin{tabular}{|c|c|c|c|c|c|c|c|c|c|c|c|c|}
\hline Character & & DH & DM & GFP & GFR & PH & $\mathbf{S} / \mathbf{M}^{2}$ & GY & G/S & 1000GW & SY & HI \\
\hline SOV & d.f & & & & & & MS & & & & & \\
\hline Years (Y) & 1 & $4746.72 * *$ & $8120.38^{* *}$ & $450.15^{* *}$ & $6257.10^{* *}$ & $9226.34 * *$ & $164000^{* *}$ & $1193.60^{* *}$ & $223.10^{*}$ & $205.39^{* *}$ & $83.44^{* *}$ & $53.94 * *$ \\
\hline Sowing dates (S) & 1 & $1157.63^{* *}$ & $5976.21 * *$ & $1873.34 * *$ & $19768.04 * *$ & $2958.48^{* *}$ & $2062165^{* *}$ & $4111.80 * *$ & $3565.93 * *$ & $4843.24 * *$ & $22.17 * *$ & $3240.26^{* *}$ \\
\hline $\mathbf{Y} * \mathbf{S}$ & 1 & $108.48^{* *}$ & $9.52 \mathrm{~ns}$ & $53.72 *$ & $474.80^{* *}$ & $162.05^{*}$ & $99134 * *$ & $58.97 * *$ & $314.88^{* *}$ & $92.39^{* *}$ & $0.42 * *$ & $8.2 \ln . \mathrm{s}$ \\
\hline Error & 8 & 2.85 & 7.95 & 5.16 & 10.52 & 19.35 & 5843 & 2.91 & 23.06 & 3.99 & 0.02 & 2.57 \\
\hline Genotypes (G) & 13 & $245.15^{* *}$ & $123.34 * *$ & $42.46^{* *}$ & $450.37 * *$ & $209.35^{* *}$ & $15498^{* *}$ & $39.23 * *$ & $352.09 * *$ & $39.65^{* *}$ & $1.91 * *$ & $22.88^{* *}$ \\
\hline$Y^{*} \mathbf{G}$ & 13 & $25.05^{* *}$ & $28.96^{* *}$ & $34.98^{* *}$ & $83.09^{* *}$ & $76.02 * *$ & $6498 * *$ & $6.49 * *$ & $202.26^{* *}$ & $14.29^{* *}$ & $0.57^{* *}$ & $11.20^{* *}$ \\
\hline $\mathbf{S}^{*} \mathbf{G}$ & 13 & $22.55^{* *}$ & $7.46^{* *}$ & $20.04 * *$ & $121.70^{* *}$ & $45.98^{* *}$ & $6239 * *$ & $16.84^{* *}$ & $62.23 * *$ & $23.12^{* *}$ & $0.16^{*}$ & $10.12 * *$ \\
\hline $\mathbf{Y} * \mathbf{S} * \mathbf{G}$ & 13 & $12.00 * *$ & $17.41^{* *}$ & $5.35^{* *}$ & $84.44 * *$ & $24.55^{* *}$ & $6796^{* *}$ & $7.42 * *$ & $50.26^{*}$ & $14.33^{* *}$ & $0.28 * *$ & $17.24 * *$ \\
\hline Error & 104 & 1.19 & 1.90 & 1.76 & 13.03 & 8.45 & 1074 & 1.47 & 26.81 & 3.03 & 0.07 & 2.73 \\
\hline CV\% & & 1.3 & 1 & 2.6 & 6.1 & 2.8 & 8.7 & 6 & 10.3 & 4.3 & 5.8 & 4.3 \\
\hline
\end{tabular}

Ns, $*, * *=$ not significant, significant at $\mathrm{P} \leq 0.05$ and $\leq 0.01$ level of probability, respectively.

DH: Days to heading, DM: days to maturity, GFP: grain filling period, GFR: grain filling rate, $\mathrm{PH}$ : plant height $(\mathrm{cm}), \mathrm{S} / \mathrm{M}^{2}$ : No. of spikes $/ \mathrm{m}^{2}$, GY: grain yield,(ardab/fad.), G/S: No. of grains / spike, $1000 \mathrm{GW}$ : weight of 1000 grains (g), SY: straw yield (ton/fad.) and HI: harvest index (\%).

Differently responded to the different environmental conditions suggesting the importance of the assessment of genotypes under different environments in order to identify the best genetic make up for a particular environment. Similar findings were obtained by Menshawy (2007) and Hamam and Khaled (2009).

\section{Mean Performance}

The results in Table 4 show the mean performance for all studied characters under the two sowing dates in the two years. Sids 4 and line 10 were the earliest genotypes in days to heading and days to maturity and Sids 4 was the highest genotypes for No. of grains/spike. Line 5 has the lowest value for grain filling period. On the other hand, Misr 2 was the best genotype for grain filling rate (short filling period), plant height, No. of spikes $/ \mathrm{m}^{2}$, grain and straw yields. Regarding the harvest index, the best genotype was Line 7. Genotypes Sids 4, Misr 2, Line 5 and Line 7 can be used for improve studied characters.

\section{Effect of Years}

The results in Tables 5 and 6 illustrates the effect of years on all studied genotypes and characters. For all studied characters, values were significantly decreased in the second season compared to the first season except for No. of grains/spike, 1000 grain weight and harvest index which had higher values in the second season compared to the first one for most genotypes. These decreases, in the values for studied characters, were due to the increase in temperature in the second season comparing with the first one (Table 2). No. of grains/spike did not effected by years, this result may be due to non-sensitivity of this character to the variation in environment conditions. Menshawy (2007) imported that 1000 grains weight and harvest index reported high values in the second season compared to the first season. Similar findings were reported by Seleiman et al. (2011) and Wahid et al. (2017). The reduction in No. of spikes $/ \mathrm{m}^{2}$ might be a reason in increase these characters in the second season.

\section{Effect of Sowing Date}

The effect of sowing date on all characters are presented in Tables 7 and 8. All studied characteristics were significantly affected by sowing date and recorded the highest values in recommended sowing date compared with those resulted from late one. Generally, the weather conditions during the last 10 days of Nov., were favorable for wheat germination. GDD in recommended sowing were 2046.6 and 2488.1 while, in late sowing they were 1679.4 and 
Zagazig J. Agric. Res., Vol. 47 No. (1) 2020

Table 4. Mean performance for all studied characters over the two seasons

\begin{tabular}{lccccccccccc}
\hline Character & DH & DM & GFP & GFR & PH & S/M & G/S & 1000GW & GY & SY & HI \\
\hline Genotype & & & & & & & & & & & \\
Sids 4 & 77 & 129 & 51 & 48.7 & 106 & 269 & 66 & 41.8 & 16.8 & 3.6 & 39.6 \\
Misr2 & 94 & 142 & 48 & 73.4 & 115 & 417 & 50 & 37.2 & 23.6 & 5.3 & 40.1 \\
Line 1 & 85 & 133 & 48 & 63.2 & 102 & 381 & 52 & 41.0 & 20.3 & 4.6 & 39.2 \\
Line 2 & 81 & 132 & 51 & 59.0 & 108 & 381 & 48 & 41.7 & 20.5 & 4.8 & 38.6 \\
Line 3 & 80 & 132 & 52 & 55.0 & 102 & 378 & 53 & 38.3 & 19.3 & 4.8 & 37.2 \\
Line 4 & 83 & 132 & 49 & 61.9 & 105 & 395 & 49 & 42.2 & 20.5 & 5 & 37.8 \\
Line 5 & 85 & 132 & 47 & 59.1 & 100 & 404 & 50 & 40.0 & 18.7 & 4.6 & 37.8 \\
Line 6 & 78 & 129 & 51 & 58.0 & 105 & 372 & 50 & 40.1 & 20.1 & 4.4 & 39.2 \\
Line 7 & 78 & 130 & 52 & 61.8 & 104 & 348 & 53 & 42.6 & 21.9 & 4.5 & 41.1 \\
Line 8 & 79 & 131 & 52 & 65.4 & 104 & 402 & 51 & 44.0 & 23.1 & 5.1 & 39.6 \\
Line 9 & 80 & 131 & 52 & 51.8 & 108 & 377 & 46 & 41.1 & 18.2 & 4.7 & 35.9 \\
Line 10 & 77 & 129 & 52 & 55.6 & 106 & 383 & 43 & 39.4 & 19.6 & 4.8 & 37.3 \\
Line 11 & 80 & 130 & 51 & 56.0 & 101 & 372 & 45 & 40.9 & 19.1 & 4.3 & 39.7 \\
Line 12 & 78 & 131 & 53 & 56.0 & 99 & 407 & 46 & 38.9 & 20.5 & 4.5 & 38.5 \\
LSD (0.05) & 0.9 & 1.1 & 1.1 & 2.9 & 2.4 & 26.5 & 4.2 & 1.41 & 0.98 & 0.22 & 1.04 \\
\hline
\end{tabular}

Where, DH: days to heading, DM: days to maturity, GFP: grain filling period, GFR: grain filling rate, PH : plant height $(\mathrm{cm})$, $\mathrm{S} / \mathrm{M}^{2}$ : No. of spikes $/ \mathrm{m}^{2}, \mathrm{G} / \mathrm{S}$ : No. of grains/spike, $1000 \mathrm{GW}$ : weight of 1000 grains (g), GY: grain yield,(ardab/fad.), SY: straw yield (ton/fad.) and HI: harvest index (\%).

Table 5. Effect of the interaction between years and genotypes on days to heading, days to maturity, grain filling period, grain filling rate, plant height and No. of spikes $/ \mathrm{m}^{2}$ during two seasons

\begin{tabular}{|c|c|c|c|c|c|c|c|c|c|c|c|c|}
\hline Character & \multicolumn{2}{|c|}{ DH } & \multicolumn{2}{|c|}{ DM } & \multicolumn{2}{|c|}{ GFP } & \multicolumn{2}{|c|}{ GFR } & \multicolumn{2}{|c|}{ PH } & \multicolumn{2}{|c|}{$\mathbf{S} / \mathbf{M}^{2}$} \\
\hline Year & \multicolumn{2}{|c|}{ 2016/17 2017/18 } & 2016/17 & 2017/18 & \multicolumn{2}{|c|}{ 2016/17 2017/18 } & \multicolumn{2}{|c|}{ 2016/17 2017/18 } & \multicolumn{2}{|c|}{ 2016/17 2017/18 } & \multicolumn{2}{|c|}{ 2016/17 2017/18 } \\
\hline \multicolumn{13}{|l|}{ Genotype } \\
\hline Sids 4 & 81 & 72 & 136 & 122 & 54 & 49 & 52.5 & 45.0 & 112 & 101 & 259 & 279 \\
\hline Misr2 & 98 & 91 & 145 & 139 & 49 & 47 & 79.8 & 67.1 & 117 & 113 & 509 & 324 \\
\hline Line 1 & 90 & 77 & 139 & 126 & 48 & 48 & 73.1 & 53.3 & 112 & 92 & 420 & 342 \\
\hline Line 2 & 86 & 73 & 140 & 125 & 52 & 51 & 66.0 & 52.0 & 115 & 100 & 411 & 351 \\
\hline Line 3 & 83 & 75 & 140 & 123 & 56 & 48 & 57.8 & 52.3 & 113 & 91 & 407 & 348 \\
\hline Line 4 & 86 & 78 & 139 & 124 & 52 & 46 & 66.2 & 57.7 & 113 & 96 & 440 & 351 \\
\hline Line 5 & 91 & 75 & 138 & 126 & 46 & 49 & 68.1 & 50.2 & 109 & 91 & 447 & 361 \\
\hline Line 6 & 82 & 72 & 135 & 123 & 52 & 50 & 63.5 & 52.4 & 112 & 98 & 396 & 348 \\
\hline Line 7 & 83 & 72 & 138 & 123 & 54 & 50 & 71.9 & 51.8 & 111 & 98 & 386 & 310 \\
\hline Line 8 & 84 & 71 & 139 & 122 & 54 & 50 & 70.5 & 60.4 & 110 & 98 & 436 & 368 \\
\hline Line 9 & 84 & 73 & 139 & 124 & 54 & 50 & 57.9 & 45.7 & 113 & 103 & 395 & 359 \\
\hline Line 10 & 81 & 72 & 139 & 120 & 57 & 48 & 58.2 & 53.0 & 112 & 101 & 388 & 378 \\
\hline Line 11 & 84 & 74 & 136 & 125 & 51 & 50 & 59.6 & 52.3 & 112 & 91 & 387 & 357 \\
\hline Line 12 & 81 & 72 & 138 & 124 & 55 & 51 & 65.6 & 46.5 & 107 & 90 & 442 & 372 \\
\hline LSD (0.05) & \multicolumn{2}{|c|}{1.3} & \multicolumn{2}{|c|}{1.8} & \multicolumn{2}{|c|}{1.6} & \multicolumn{2}{|c|}{4.1} & \multicolumn{2}{|c|}{3.5} & \multicolumn{2}{|c|}{43.4} \\
\hline
\end{tabular}

Where, DH: days to heading, DM: days to maturity, GFP: grain filling period, GFR: grain filling rate, PH : plant height $(\mathrm{cm})$, $\mathrm{S} / \mathrm{M}^{2}$ : No. of spikes $/ \mathrm{m}^{2}$. 
Table 6. Effect of the interaction between years and genotypes on No. of grains/spike, weight of 1000 grains, grain yield, straw yield and harvest index

\begin{tabular}{|c|c|c|c|c|c|c|c|c|c|c|}
\hline \multirow{2}{*}{$\begin{array}{l}\text { Character } \\
\text { Year }\end{array}$} & \multicolumn{2}{|c|}{ G/S } & \multicolumn{2}{|c|}{ 1000GW } & \multicolumn{2}{|c|}{ GY } & \multicolumn{2}{|c|}{ SY } & \multicolumn{2}{|c|}{ HI } \\
\hline & $2016 / 17$ & $2017 / 18$ & $2016 / 17$ & $2017 / 18$ & $2016 / 17$ & $2017 / 18$ & $2016 / 17$ & $2017 / 18$ & $2016 / 17$ & $2017 / 18$ \\
\hline \multicolumn{11}{|l|}{ Genotype } \\
\hline Sids 4 & 58 & 74 & 41.3 & 42.3 & 18.8 & 14.9 & 3.8 & 3.5 & 40.6 & 38.5 \\
\hline Misr2 & 40 & 59 & 36.0 & 38.5 & 25.9 & 21.2 & 6.4 & 4.2 & 37.8 & 42.5 \\
\hline Line 1 & 50 & 54 & 41.5 & 40.5 & 23.4 & 17.3 & 5.4 & 3.9 & 39.0 & 39.5 \\
\hline Line 2 & 46 & 50 & 41.3 & 42.1 & 23.0 & 17.9 & 5.7 & 3.9 & 37.0 & 40.2 \\
\hline Line 3 & 57 & 50 & 36.3 & 40.4 & 21.7 & 16.9 & 5.6 & 4.0 & 36.3 & 38.0 \\
\hline Line 4 & 50 & 47 & 41.0 & 43.4 & 23.3 & 17.8 & 5.7 & 4.2 & 37.4 & 38.2 \\
\hline Line 5 & 51 & 49 & 39.9 & 40.1 & 20.8 & 16.6 & 5.2 & 3.9 & 37.2 & 38.3 \\
\hline Line 6 & 47 & 52 & 36.5 & 43.7 & 22.5 & 17.7 & 5.1 & 3.8 & 38.1 & 40.4 \\
\hline Line 7 & 49 & 57 & 39.6 & 45.5 & 26.0 & 17.7 & 5.4 & 3.7 & 40.9 & 41.4 \\
\hline Line 8 & 54 & 49 & 43.2 & 44.8 & 25.8 & 20.4 & 5.7 & 4.6 & 39.6 & 39.6 \\
\hline Line 9 & 50 & 42 & 40.7 & 41.6 & 21.0 & 15.3 & 5.4 & 4.0 & 36.4 & 35.5 \\
\hline Line 10 & 41 & 45 & 38.1 & 40.6 & 22.2 & 17.0 & 5.7 & 3.9 & 35.6 & 39.0 \\
\hline Line 11 & 44 & 46 & 40.1 & 41.8 & 20.5 & 17.7 & 4.8 & 3.8 & 38.7 & 40.7 \\
\hline Line 12 & 49 & 44 & 38.2 & 39.5 & 24.6 & 16.4 & 5.2 & 3.9 & 39.2 & 37.7 \\
\hline LSD (0.05) & \multicolumn{2}{|c|}{5.9} & \multicolumn{2}{|c|}{2.01} & \multicolumn{2}{|c|}{1.44} & \multicolumn{2}{|c|}{0.3} & \multicolumn{2}{|c|}{1.89} \\
\hline
\end{tabular}

Where, G/S: No. of grains/spike, 1000GW: weight of 1000 grains (g), GY: grain yield (ardab/fad.), SY: straw yield (ton/fad.) and $\mathrm{HI}$ : harvest index $(\%)$.

Table 7. Effect of the interaction between sowing dates and genotypes on days to heading and maturity, grain filling period, and rate, plant height and No. of spikes $/ \mathrm{m}^{2}$

\begin{tabular}{|c|c|c|c|c|c|c|c|c|c|c|c|c|}
\hline \multirow{2}{*}{$\begin{array}{l}\text { Character } \\
\text { Sowing date }\end{array}$} & \multicolumn{2}{|c|}{ DH } & \multicolumn{2}{|c|}{ DM } & \multicolumn{2}{|c|}{ GFP } & \multicolumn{2}{|c|}{ GFR } & \multicolumn{2}{|c|}{ PH } & \multicolumn{2}{|c|}{$\mathbf{S M}^{2}$} \\
\hline & $\mathbf{R S}$ & $\mathbf{L S}$ & RS & $\mathbf{L S}$ & RS & $\mathbf{L S}$ & RS & $\mathbf{L S}$ & $\mathbf{R S}$ & $\mathbf{L S}$ & $\mathbf{R S}$ & $\mathbf{L S}$ \\
\hline \multicolumn{13}{|l|}{ Genotype } \\
\hline Sids 4 & 80 & 75 & 134 & 123 & 55 & 48 & 54.0 & 43.5 & 108 & 104 & 315 & 223 \\
\hline Misr 2 & 100 & 88 & 149 & 134 & 49 & 47 & 86.4 & 60.5 & 122 & 108 & 513 & 320 \\
\hline Line 1 & 88 & 81 & 139 & 126 & 51 & 45 & 74.1 & 52.3 & 103 & 100 & 486 & 276 \\
\hline Line 2 & 83 & 79 & 138 & 127 & 55 & 48 & 70.6 & 47.5 & 113 & 102 & 477 & 285 \\
\hline Line 3 & 82 & 77 & 138 & 126 & 55 & 49 & 64.4 & 45.7 & 103 & 101 & 485 & 270 \\
\hline Line 4 & 85 & 80 & 137 & 126 & 52 & 46 & 72.8 & 51.1 & 110 & 99 & 515 & 276 \\
\hline Line 5 & 88 & 81 & 138 & 127 & 49 & 46 & 70.2 & 48.1 & 102 & 98 & 524 & 284 \\
\hline Line 6 & 80 & 76 & 134 & 123 & 54 & 48 & 76.7 & 39.3 & 112 & 98 & 484 & 260 \\
\hline Line 7 & 80 & 77 & 136 & 125 & 56 & 48 & 75.4 & 48.2 & 107 & 102 & 478 & 218 \\
\hline Line 8 & 82 & 76 & 138 & 124 & 56 & 48 & 76.8 & 54.1 & 109 & 99 & 523 & 282 \\
\hline Line 9 & 82 & 76 & 136 & 126 & 54 & 50 & 62.9 & 40.8 & 113 & 103 & 505 & 250 \\
\hline Line 10 & 78 & 76 & 134 & 124 & 56 & 49 & 63.5 & 47.7 & 112 & 101 & 510 & 256 \\
\hline Line 11 & 82 & 78 & 137 & 124 & 55 & 46 & 63.1 & 48.8 & 107 & 96 & 474 & 271 \\
\hline Line 12 & 79 & 76 & 138 & 123 & 60 & 47 & 66.2 & 45.8 & 102 & 96 & 547 & 267 \\
\hline LSD (0.05) & \multicolumn{2}{|c|}{1.3} & \multicolumn{2}{|c|}{1.8} & \multicolumn{2}{|c|}{1.6} & \multicolumn{2}{|c|}{4.1} & \multicolumn{2}{|c|}{3.5} & \multicolumn{2}{|c|}{43.4} \\
\hline
\end{tabular}

Where, RS: recommended sowing date, LS: late sowing date, DH: days to heading, DM: days to maturity, GFP: grain filling period, GFR: grain filling rate, $\mathrm{PH}$ : plant height $(\mathrm{cm}), \mathrm{S} / \mathrm{M}^{2}$ : No. of spikes $/ \mathrm{m}^{2}$. 
Table 8. Effect of the interaction between sowing dates and genotypes on No. of grains/spike, 1000-grain weight (g), grain yield (ardab/fad.), straw yield (ton/fas.) and harvest index (\%)

\begin{tabular}{|c|c|c|c|c|c|c|c|c|c|c|}
\hline \multirow{2}{*}{$\begin{array}{l}\text { Character } \\
\text { Sowing dates }\end{array}$} & \multicolumn{2}{|c|}{ GS } & \multicolumn{2}{|c|}{ 1000GW } & \multicolumn{2}{|c|}{ GY } & \multicolumn{2}{|c|}{ SY } & \multicolumn{2}{|c|}{ HI } \\
\hline & $\mathbf{R S}$ & $\mathbf{L S}$ & $\mathbf{R S}$ & LS & $\mathbf{R S}$ & LS & RS & $\mathbf{L S}$ & $\mathbf{R S}$ & $\mathbf{L S}$ \\
\hline \multicolumn{11}{|l|}{ Genotype } \\
\hline Sids 4 & 72 & 59 & 48.2 & 35.4 & 19.7 & 13.9 & 3.8 & 3.5 & 44.9 & 34.2 \\
\hline Misr2 & 54 & 45 & 39.8 & 34.7 & 28.2 & 18.9 & 5.7 & 4.9 & 43.5 & 36.8 \\
\hline Line 1 & 57 & 47 & 44.7 & 37.3 & 24.8 & 15.8 & 5.0 & 4.3 & 42.8 & 35.6 \\
\hline Line 2 & 49 & 47 & 47.7 & 35.8 & 25.9 & 15.1 & 5.1 & 4.4 & 43.9 & 33.3 \\
\hline Line 3 & 60 & 46 & 44.6 & 32.0 & 23.7 & 14.9 & 5.1 & 4.5 & 41.1 & 33.3 \\
\hline Line 4 & 53 & 44 & 47.1 & 37.4 & 25.5 & 15.6 & 5.3 & 4.6 & 42.1 & 33.5 \\
\hline Line 5 & 58 & 42 & 45.7 & 34.3 & 22.8 & 14.6 & 4.8 & 4.3 & 41.6 & 33.9 \\
\hline Line 6 & 56 & 44 & 47.7 & 32.5 & 27.8 & 12.5 & 5.1 & 3.8 & 44.9 & 33.6 \\
\hline Line 7 & 60 & 46 & 48.9 & 36.2 & 28.2 & 15.5 & 5.0 & 4.1 & 45.8 & 36.5 \\
\hline Line 8 & 57 & 45 & 49.7 & 38.3 & 28.7 & 17.4 & 5.6 & 4.7 & 43.3 & 35.9 \\
\hline Line 9 & 47 & 45 & 47.1 & 35.2 & 22.7 & 13.7 & 5.0 & 4.5 & 40.6 & 31.3 \\
\hline Line 10 & 47 & 39 & 42.8 & 35.9 & 23.7 & 15.4 & 5.1 & 4.5 & 41.6 & 33.0 \\
\hline Line 11 & 47 & 43 & 45.3 & 36.6 & 23.2 & 15.0 & 4.7 & 3.9 & 42.6 & 36.8 \\
\hline Line 12 & 49 & 44 & 45.2 & 32.5 & 26.5 & 14.5 & 4.9 & 4.1 & 44.4 & 32.5 \\
\hline LSD (0.05) & \multicolumn{2}{|c|}{5.9} & \multicolumn{2}{|c|}{2.01} & \multicolumn{2}{|c|}{1.44} & \multicolumn{2}{|c|}{0.3} & \multicolumn{2}{|c|}{1.89} \\
\hline
\end{tabular}

Where, RS: recommended sowing date, LS: late sowing date, G/S: No. of grains/spike, 1000GW: weight of 1000 grains (g), GY: grain yield,(ardab/fad.), SY: straw yield (ton/fad.) and HI: harvest index (\%).

1981.7 in both seasons, respectively. Other stages would have the suitable condition starting from Dec., up to the end of the season (usually to late Apr., or to the first week of May). Moreover, it is well known that weather almost plays important roles with all the characteristics especially on yield and yield components.

These results were in good agreement with those reported by Tawfelis et al. (2006), Talukder (2014), Menshawy et al. (2015) and Yadav et al. (2018). Menshawy et al. (2015) recorded that timing of initiation of vegetative and reproductive organs depends upon temperature and photoperiod, but the survival and subsequent size of such organs is dependent upon the supply of assimilates. The choice of sowing date is, therefore, vital to ensure both sufficient grain sitting initiated and sufficient assimilates. Amal et al. (2016) indicated that late sowing of wheat subjected the grains to low soil temperatures causing poor emergence, and high temperatures at the end of season, which might adversely affect reproductive growth stage.

\section{The Interaction Effect}

The effect of interaction among seasons, sowing dates and genotypes on all studied characters are shown in Tables 9, 10 and 11. The late sowing date in the two growing seasons showed a reduction in the means of all studied characters. In this respect, Menshawy (2007), reported that environmental factors, viz., temperature and day length were distinct at the time of sowing and during crop growth under different natural photothermal environments. The all studied genotypes had shortened duration of pre-heading and maturing under the late sowing in the seasons. Under the recommended sowing date (OS), the studied genotypes were earlier in 2017/2018 comparing to the first season. These results reflected the differences in climatic conditions during the two growing seasons (Table 2). Similar results were obtained by Rahmani et al. (2013) and Talukder et al. (2014).

\section{The Relationship between Recommended and Late Sowing Date on Grain Yield}

The results presented in Table 12 show the grain yield for all genotypes as a mean of the 
Aglan, et al.

Table 9. Mean values of days to heading and maturity, grain filling period and rate for $\mathbf{1 4}$ wheat genotypes under sowing dates during 2016/2017 and 2017/2018 seasons

\begin{tabular}{|c|c|c|c|c|c|c|c|c|c|c|c|c|c|c|c|c|}
\hline \multirow{2}{*}{$\begin{array}{l}\text { Character } \\
\text { Years }\end{array}$} & \multicolumn{4}{|c|}{ DH } & \multicolumn{4}{|c|}{ DM } & \multicolumn{4}{|c|}{ GFP } & \multicolumn{4}{|c|}{ GFR } \\
\hline & \multicolumn{4}{|c|}{$2016 / 20172017 / 2018$} & \multicolumn{4}{|c|}{$2016 / 20172017 / 2018$} & \multicolumn{8}{|c|}{$2016 / 20172017 / 20182016 / 2017 \quad 2017 / 2018$} \\
\hline$\overline{\text { Sowing date }}$ & RS & $\mathbf{L S}$ & $\mathbf{R S}$ & $\mathbf{L S}$ & $\mathbf{R S}$ & $\mathbf{L S}$ & $\mathbf{R S}$ & $\mathbf{L S}$ & $\mathbf{R S}$ & $\mathbf{L S}$ & $\mathbf{R S}$ & $\mathbf{L S}$ & $\mathbf{R S}$ & $\mathbf{L S}$ & $\mathbf{R S}$ & $\mathbf{L S}$ \\
\hline \multicolumn{17}{|l|}{ Genotype } \\
\hline Sids 4 & 85 & 79 & 74 & 71 & 143 & 128 & 126 & 117 & 58 & 49 & 52 & 47 & 54.4 & 50.5 & 53.5 & 36.5 \\
\hline Misr 2 & 106 & 86 & 95 & 89 & 156 & 134 & 143 & 135 & 50 & 48 & 48 & 46 & 93.1 & 66.5 & 79.7 & 54.5 \\
\hline Line 1 & 97 & 86 & 80 & 76 & 146 & 132 & 132 & 121 & 49 & 46 & 52 & 45 & 87.5 & 58.8 & 60.6 & 45.9 \\
\hline Line 2 & 90 & 86 & 76 & 72 & 145 & 134 & 131 & 119 & 55 & 48 & 55 & 47 & 79.6 & 52.3 & 61.5 & 42.6 \\
\hline Line 3 & 88 & 80 & 77 & 74 & 146 & 134 & 129 & 118 & 58 & 54 & 52 & 44 & 68.7 & 46.9 & 60.1 & 44.5 \\
\hline Line 4 & 90 & 84 & 80 & 77 & 144 & 134 & 130 & 118 & 54 & 50 & 50 & 41 & 78.1 & 54.2 & 67.6 & 47.9 \\
\hline Line 5 & 98 & 88 & 79 & 74 & 144 & 133 & 131 & 121 & 47 & 45 & 52 & 47 & 80.6 & 55.5 & 59.8 & 40.7 \\
\hline Line 6 & 86 & 80 & 74 & 72 & 140 & 130 & 129 & 117 & 54 & 50 & 54 & 45 & 90.0 & 37.1 & 63.4 & 41.4 \\
\hline Line & 87 & 82 & 73 & 71 & 143 & 132 & 128 & 117 & 57 & 50 & 55 & 46 & 90.0 & 53.7 & 60.9 & 42.8 \\
\hline Line 8 & 88 & 82 & 75 & 70 & 146 & 132 & 129 & 116 & 58 & 50 & 54 & 46 & 83.7 & 57.4 & 69.9 & 50.8 \\
\hline Line 9 & 88 & 81 & 77 & 72 & 143 & 134 & 130 & 119 & 55 & 53 & 53 & 46 & 68.2 & 47.6 & 57.5 & 34.0 \\
\hline Line 10 & 84 & 81 & 73 & 71 & 143 & 135 & 126 & 114 & 59 & 54 & 52 & 43 & 68.9 & 47.5 & 58.0 & 47.9 \\
\hline Line 11 & 87 & 83 & 76 & 73 & 142 & 130 & 132 & 118 & 55 & 47 & 55 & 45 & 68.8 & 50.5 & 57.4 & 47.2 \\
\hline Line 12 & 83 & 82 & 74 & 71 & 145 & 131 & 132 & 116 & 62 & 49 & 58 & 45 & 74.3 & 56.8 & 58.2 & 34.8 \\
\hline LSD (0.05) & \multicolumn{4}{|c|}{1.8} & \multicolumn{4}{|c|}{2.5} & \multicolumn{4}{|c|}{2.3} & \multicolumn{4}{|c|}{5.8} \\
\hline
\end{tabular}

Where, RS: recommended sowing date, LS: late sowing date, DH: days to heading, DM: days to maturity, GFP: grain filling period, GFR: grain filling rate,

Table 10. Mean values of plant height, No. of spikes $/ \mathrm{m}^{2}$, No. of grains/spik and, 1000-grain weight (g) during 2016/2017 and 2017/2018 seasons

\begin{tabular}{|c|c|c|c|c|c|c|c|c|c|c|c|c|c|c|c|c|}
\hline \multirow{2}{*}{$\begin{array}{l}\text { Character } \\
\text { Year }\end{array}$} & \multicolumn{4}{|c|}{$\mathbf{P H}$} & \multicolumn{4}{|c|}{$\mathbf{S} / \mathbf{M}^{2}$} & \multicolumn{4}{|c|}{ GS } & \multicolumn{4}{|c|}{$1000 \mathrm{GW}$} \\
\hline & \multicolumn{2}{|c|}{$2016 / 2017$} & \multicolumn{2}{|c|}{$2017 / 2018$} & \multicolumn{2}{|c|}{$2016 / 2017$} & \multicolumn{2}{|c|}{$2017 / 2018$} & \multicolumn{2}{|c|}{$2016 / 2017$} & \multicolumn{2}{|c|}{$2017 / 2018$} & \multicolumn{2}{|c|}{$2016 / 2017$} & \multicolumn{2}{|c|}{$2017 / 2018$} \\
\hline Sowing dates & $\mathbf{R S}$ & LS & RS & LS & RS & $\mathbf{L S}$ & RS & $\mathbf{L S}$ & RS & $\mathbf{L S}$ & $\mathbf{R S}$ & $\mathbf{L S}$ & $\mathbf{R S}$ & $\mathbf{L S}$ & RS & $\mathbf{L S}$ \\
\hline \multicolumn{17}{|l|}{ Genotype } \\
\hline Sids 4 & 113 & 110 & 103 & 98 & 282 & 236 & 348 & 209 & 67 & 49 & 78 & 70 & 47.0 & 35.6 & 49.4 & 35.1 \\
\hline Misr2 & 128 & 107 & 117 & 110 & 600 & 418 & 427 & 221 & 45 & 34 & 63 & 56 & 37.8 & 34.2 & 41.8 & 35.1 \\
\hline Line 1 & 113 & 110 & 93 & 90 & 553 & 288 & 419 & 264 & 53 & 47 & 61 & 47 & 45.3 & 37.6 & 44.1 & 36.9 \\
\hline Line 2 & 123 & 107 & 103 & 97 & 543 & 278 & 410 & 291 & 51 & 42 & 47 & 52 & 48.0 & 34.7 & 47.3 & 37.0 \\
\hline Line 3 & 115 & 112 & 92 & 90 & 513 & 302 & 457 & 239 & 68 & 46 & 53 & 47 & 42.5 & 30.0 & 46.7 & 34.0 \\
\hline Line 4 & 120 & 107 & 100 & 92 & 585 & 294 & 445 & 258 & 55 & 45 & 51 & 44 & 46.4 & 35.6 & 47.7 & 39.2 \\
\hline Line 5 & 110 & 108 & 95 & 87 & 601 & 293 & 447 & 275 & 63 & 39 & 52 & 45 & 46.7 & 33.1 & 44.7 & 35.5 \\
\hline Line 6 & 122 & 103 & 102 & 93 & 531 & 262 & 437 & 258 & 55 & 40 & 57 & 48 & 47.4 & 25.7 & 47.9 & 39.4 \\
\hline Line 7 & 115 & 107 & 98 & 97 & 549 & 222 & 408 & 213 & 58 & 39 & 61 & 52 & 47.6 & 31.6 & 50.2 & 40.9 \\
\hline Line 8 & 115 & 105 & 103 & 93 & 611 & 262 & 435 & 301 & 60 & 47 & 54 & 43 & 48.8 & 37.7 & 50.6 & 38.9 \\
\hline Line 9 & 120 & 107 & 107 & 100 & 535 & 255 & 475 & 244 & 48 & 51 & 45 & 38 & 47.7 & 33.7 & 46.5 & 36.7 \\
\hline Line 10 & 118 & 105 & 105 & 97 & 579 & 197 & 442 & 314 & 47 & 35 & 48 & 43 & 42.3 & 34.0 & 43.3 & 37.8 \\
\hline Line 11 & 118 & 105 & 95 & 87 & 504 & 271 & 444 & 271 & 45 & 43 & 48 & 44 & 45.2 & 34.9 & 45.4 & 38.2 \\
\hline Line 12 & 110 & 105 & 93 & 87 & 629 & 254 & 465 & 280 & 52 & 45 & 45 & 42 & 46.6 & 29.8 & 43.9 & 35.1 \\
\hline LSD (0.05) & \multicolumn{4}{|c|}{4.9} & \multicolumn{4}{|c|}{61.4} & \multicolumn{4}{|c|}{8.3} & \multicolumn{4}{|c|}{2.85} \\
\hline
\end{tabular}

Where, RS: recommended sowing date, LS: late sowing date, $\mathrm{PH}$ : plant height, $\mathrm{S} / \mathrm{M}^{2}$, No. of spikes $/ \mathrm{m}^{2}$,

G/S: No. of grains / spike, $1000 \mathrm{GW}$ : weight of 1000 grains (g). 
Zagazig J. Agric. Res., Vol. 47 No. (1) 2020

Table 11. Mean values of the grain and straw yields and harvest index for 14 wheat genotypes under sowing dates during 2016/2017 and 2017/2018 seasons

\begin{tabular}{|c|c|c|c|c|c|c|c|c|c|c|c|c|}
\hline \multirow{3}{*}{$\begin{array}{l}\text { Character } \\
\text { Year } \\
\text { Sowing dates } \\
\end{array}$} & \multicolumn{4}{|c|}{ GY } & \multicolumn{4}{|c|}{$\begin{array}{c}\text { SY } \\
\end{array}$} & \multicolumn{4}{|c|}{ HI } \\
\hline & \multicolumn{2}{|c|}{$2016 / 2017$} & \multicolumn{2}{|c|}{$2017 / 2018$} & \multicolumn{2}{|c|}{$2016 / 2017$} & \multicolumn{2}{|c|}{$2017 / 2018$} & \multicolumn{2}{|c|}{$2016 / 2017$} & \multicolumn{2}{|c|}{$2017 / 2018$} \\
\hline & $\mathbf{R S}$ & $\mathbf{L S}$ & $\mathbf{R S}$ & $\mathbf{L S}$ & $\mathbf{R S}$ & $\mathbf{L S}$ & $\mathbf{R S}$ & $\mathbf{L S}$ & $\mathbf{R S}$ & $\mathbf{L S}$ & $\mathbf{R S}$ & $\mathbf{L S}$ \\
\hline \multicolumn{13}{|l|}{$\overline{\text { Genotype }}$} \\
\hline Sids 4 & 21.0 & 16.5 & 18.4 & 11.4 & 4.0 & 3.6 & 3.6 & 3.4 & 46.4 & 34.8 & 43.4 & 33.6 \\
\hline Misr2 & 30.8 & 21.1 & 25.5 & 16.8 & 7.3 & 5.5 & 4.1 & 4.3 & 38.9 & 36.6 & 48.0 & 37.0 \\
\hline Line 1 & 28.8 & 18.0 & 20.9 & 13.7 & 5.8 & 5.0 & 4.2 & 3.6 & 42.9 & 35.1 & 42.7 & 36.2 \\
\hline Line 2 & 29.2 & 16.8 & 22.5 & 13.3 & 6.0 & 5.4 & 4.3 & 3.5 & 43.6 & 30.4 & 44.3 & 36.2 \\
\hline Line 3 & 26.7 & 16.8 & 20.8 & 12.9 & 5.9 & 5.2 & 4.3 & 3.7 & 40.3 & 32.3 & 41.8 & 34.3 \\
\hline Line 4 & 28.3 & 18.2 & 22.7 & 13.0 & 6.4 & 5.1 & 4.3 & 4.1 & 40.0 & 34.7 & 44.2 & 32.3 \\
\hline Line 5 & 25.1 & 16.5 & 20.6 & 12.7 & 5.4 & 5.0 & 4.2 & 3.6 & 41.1 & 33.3 & 42.1 & 34.5 \\
\hline Line 6 & 32.6 & 12.5 & 23.0 & 12.4 & 5.7 & 4.4 & 4.4 & 3.2 & 46.0 & 30.1 & 43.8 & 37.0 \\
\hline Line 7 & 34.0 & 18.0 & 22.4 & 13.0 & 5.9 & 4.9 & 4.1 & 3.2 & 46.4 & 35.3 & 45.3 & 37.6 \\
\hline Line 8 & 32.4 & 19.2 & 25.0 & 15.7 & 6.2 & 5.3 & 5.1 & 4.1 & 44.0 & 35.2 & 42.6 & 36.6 \\
\hline Line 9 & 25.1 & 16.9 & 20.2 & 10.5 & 5.7 & 5.2 & 4.3 & 3.8 & 39.7 & 33.0 & 41.5 & 29.5 \\
\hline Line 10 & 27.2 & 17.1 & 20.2 & 13.7 & 5.9 & 5.4 & 4.2 & 3.7 & 41.1 & 30.1 & 42.1 & 35.8 \\
\hline Line 11 & 25.2 & 15.8 & 21.2 & 14.3 & 5.2 & 4.4 & 4.2 & 3.4 & 42.3 & 35.2 & 42.9 & 38.4 \\
\hline Line 12 & 30.6 & 18.6 & 22.4 & 10.4 & 5.5 & 5.0 & 4.4 & 3.3 & 45.6 & 32.9 & 43.2 & 32.2 \\
\hline LSD (0.05) & \multicolumn{4}{|c|}{2.03} & \multicolumn{4}{|c|}{0.42} & \multicolumn{4}{|c|}{2.67} \\
\hline
\end{tabular}

Where, RS: recommended sowing date, LS: late sowing date, GY: grain yield (ardab/fad.), SY: straw yield (ton/fad.) and HI: harvest index (\%).

Table 12. Mean of grain yield in the recommended (RS) and late sowing date (LS) over the two growing seasons and tolerance index (TOL) and yield reduction ratio (YR\%)

\begin{tabular}{lcccc}
\hline Genotype & RS & LS & TOL & YR\% \\
\hline Sids 4 & 22.92 & 12.78 & 10.14 & 0.44 \\
Misr2 & 29.21 & 19.59 & 9.62 & 0.33 \\
Line 1 & 25.96 & 16.10 & 9.86 & 0.38 \\
Line 2 & 26.58 & 14.73 & 11.85 & 0.45 \\
Line 3 & 23.11 & 13.33 & 9.78 & 0.42 \\
Line 4 & 24.46 & 14.57 & 9.89 & 0.40 \\
Line 5 & 23.63 & 14.41 & 9.22 & 0.39 \\
Line 6 & 28.81 & 13.34 & 15.47 & 0.54 \\
Line 7 & 29.71 & 15.94 & 13.77 & 0.46 \\
Line 8 & 29.15 & 17.38 & 11.78 & 0.40 \\
Line 9 & 23.10 & 15.46 & 7.64 & 0.33 \\
Line 10 & 24.10 & 15.53 & 8.57 & 0.36 \\
Line 11 & 23.22 & 15.00 & 8.23 & 0.35 \\
Line 12 & 26.88 & 14.74 & 12.14 & 0.45 \\
\hline
\end{tabular}


two seasons and values of tolerance index(TOL) and yield reduction under late sowing date compared to the grain yield in recommended sowing date .From the results in Table 12, high tolerance index values were recorded for Lines 6, 7 and 12, whereas the lowest values were recorded for Lines 9, 11 and 10.

With regard to yield reduction, the lowest values were obtained by Misr 2 and line 9 and the highest values were recorded for lines 6 and 7. From this results Misr 2 the best genotype and tolerante to late sowing because its high yield potential in recommended sowing date. It has moderate value for tolerance index (9.62) and the lowest value in yield reduction $(0.33)$ under late sowing compared to other bread wheat genotypes

\section{Conclusion}

The best sowing date to gives high grain and straw yields was $23^{\text {th }}$ of November. The bread wheat cultivar Misr 2 is recommended to be growing in North Delta region in case of recommended and late sowing because his stability in the two sowing dates and low yield reduction when sowing at late sowing.

\section{Acknowledgement}

Our sincere thanks goes to wheat research department for proving necessary facility to accomplish this search. We would like to thank all staff of Sakha research station for their suggesting, moral support and necessary help during experimentation

\section{REFERENCES}

Abd El-Hamid, E.A.M. (2006). Studies on wheat breeding (Triticum aestivum L). M.Sc. Thesis, Agronomy, Fac., Agric., Kafr ElSheikh Tanta Univ. Egypt.

Abdel Nour, N.A.R. and S.A. Hayam (2011). Influence of sowing date and nitrogen fertilization on yield and its components in some bread wheat genotypes. Egypt J. Agric. Res., 89 (4): 1413-1432.

Abd El-Shafi and Ageb (1994). Breeding strategy for developing heat tolerant varieties adapted to Upper Egypt and Sudan. In: D.A. Saunders and G.P. Hetted (eds). Wheat in heat stressed environment, irrigated, dry areas, and rice-wheat farming systems. Proc. Int. Conf. on Wheat in Hot, Dry, Irrigated Environments. CIMMYT. Mexico., 33-39.

Ali, M.A., M. Ali, M. Sattar and L. Ali, (2010).Sowing date effect on yield of different wheat varieties. J. Agric. Res., 48 (2): 157-162.

Alisial, M., M.A. Arain, M.U. Dahot, G.S. Markhand, K.A. Laghari, S.M. Mangrio, A.A. Mirbahar and M.H. Naqvi (2010). Effect of sowing dates on yield and yield components on mutant -cum- hybrid lines of bread wheat. Pak. J. Bot., 42 (1): 269-277.

Amal, G., M. Ali, M.A. Omar, A.I. Nawar and S.Sh. El-Tabbakh (2016). Effect of sowing date and nitrogen fertilization level on growth and productivity of some durum and bread wheat varieties. Alex. Sci. Exc. J., 37 (4): 541-549

El-Sarag, E.I. and R.I.M. Ismaeil (2015). Evaluation of some bread wheat cultivars productivity as affected by sowing dates and water stress in semi-arid region. Asian J. Crop Sci., 5 (2): 167-178.

Gollestani, S.A. and M.T. Assad (1998). Evaluation of four screening techniques for planting late resistance and their relationship to yield reduction ratio in wheat. Euphytica, 103: 293-299.

Gomez, K.A. and A.A. Gomez (1984). Statistical Procedures for the Agricultural Researches. John Wiley and Son. Inc. New York.

Hamam and Khaled (2009). Stability of wheat genotypes under different environments and their evaluation under sowing dates and nitrogen fertilizer levels. Aust. J. Basic and Appl. Sci., 3(1): 206-217.

Menshawy, A.M.M. (2007). Evaluation of some early bread wheat genotypes under different sowing dates:1. Earliness character. Fifth Plant Breeding Conference (May). Egypt J. Plant Breed., 11(1): 25-40.

Menshawy, A.M.M., A.A. Al-Soqeer and S.M. Al-Otyak (2015). earliness, yield and heat sensitivity in bread wheat under natural heat stress. Egypt. J. Agric. Res., 93: 2 (A). 
Mostafa, H.A.M., R.A. Hassanein, S.A. Khawas, H. M.S. El-Bassiouny and A.A. Abd ElMonem (2010). Effect of arginine or putrescine on growth, yield and yield components of late sowing wheat. J. Appl. Sci. Res., 6 (2): 177-183.

Muhammad, I., F. Mohammad, I.H. Khalil, M. Arif, W. Khan and A.S.M. Saifullah (2013). Yield potential of F4:7 bread wheat (Triticum aestivum L.) lines under normal and late plantings. Int. J. Basic and Appl. Sci. IJBASIJENS, 7- 11.

Nasim, G., S. Ashraf and A. Javaid (2006). Effect of sowing time on my corrllizal development in wheat. Mycopath., 4 (1): 1319.

Parthasarathi, T.G.V. and P. Jeuakumar (2014). Impact of heat units on growth and development physiology of future crop production: A Rev. Res. and Rev.: A J. Crop Sci. and Technol., 2 (1): 2319-3395.

Rahman, M.M., A. Hosdsain, M.A. Hakim, M.R. Kabir and M.M.R. Shah (2009). Performance of wheat genotypes under optimum and sowing condition. Int. J. Sustain. Crop Prod., 4(6): 34-39.

Rahmani, A., A. Jafarnezhad, G. Taheri, M. Armin and M. Tajabadi (2013). Effect of planting date on growth and assimilate contribution on assimilates on seed yield of six wheat cultivars. Adv. Agri. Biol., 1 (4): 94-100.

Rosielle, A.A. and J. Hambling (1981). Theoretical aspects of selection for yield in stress and non- stress environments. Crop Sci., 21: 943-946.

Seleiman, M., M. Ibrahiml, S. Abdel-Aal and G. Zahran (2011). Effect of sowing dates on productivity, technological and rheological characteristics of bread wheat. J. Agron. Crop Sci., 2 (1): 1- 6.

Steel, R.G.D., J.H. Torrie and D.A. Dickey, (1997). Principles and procedures of statistics: a biometric approach, $3^{\text {rd }}$ Ed. McGraw Hill Book Co. Inc., New York. US

Singh, V.P.N. and S.K. Uttam (1999). Influence of sowing dates on yield of wheat cultivars under saline sodic conditions in Central Utter Pradesh. Indian Agric., 38 (1): 64-68.

Talukder, A.S., M.H.M.G.K. McDonald and G.S. Gill (2014). Effect of short-term heat stress prior to flowering and at early grain set on the utilization of water-soluble carbohydrate by wheat genotypes. Field Crop Res., 147 (7): 1-11

Tawfelis, M.B., A.A. El-Sherbieny and M.N. Abd El-Kader (2006). Genetic studies on grain yield and some agronomic characters in some durum wheat crosses. Egypt. J. Agric. Res., 84: 1479-1492.

Wahid, S.A., I.H.H. Al-Hilfy and H.M.K. AlAbodi (2017). Effect of sowing dates on the growth and yield of different wheat cultivars and their relationship with accumulated heat units. Ame.-Eurasian J. Sustainable Agric., 11 (3): 7-13.

Wajid, A., A. Hussain, A. Ahmad, A.R. Goheer, M. Ibrahim and M. Mussaddique (2004). Effect of sowing date and plant population on biomass, grain yield and yield components of wheat. Int. J. Agric. and Biol., 6 (6): 1003-1005.

Yadav, M., M.W. Devokta, S.K. Sah and R. Bhatt (2018). Effect of sowing date on yield and yield components of different wheat varieties. Nepalese J. Agric. Sci., 16: 96-102. 
تأثير مواعيد الزراعة على المحصول ومكوناته في بعض التراكيب الوراثية من قمح الخبز

$$
\text { قوأمن عبدالوهاب عجلان ـ السيد علي عبدالحميد ـ أمجد محمد مرسي القمح - معهد بحوث المحاصيل الحقلية ـ مركز البحوث الزر اعية ـ مصر }
$$

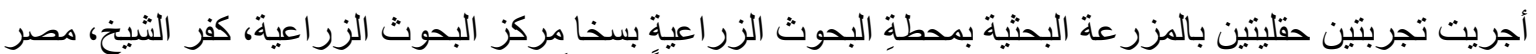

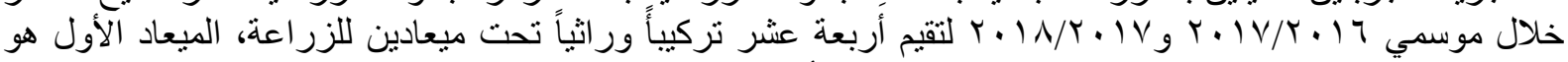

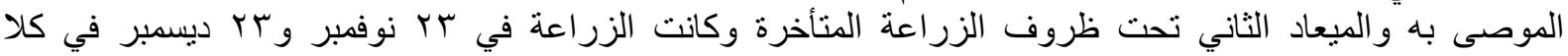

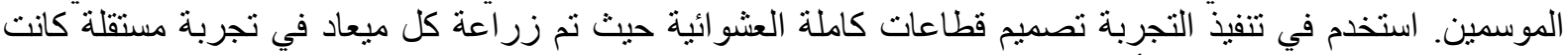

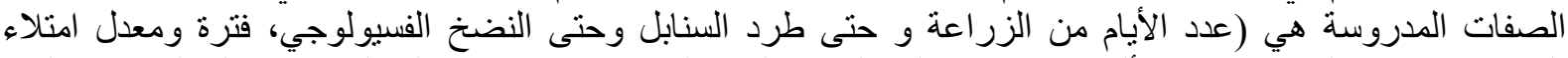

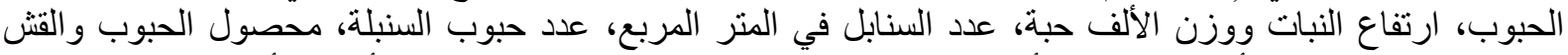

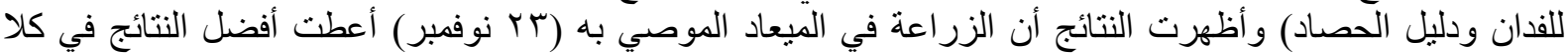

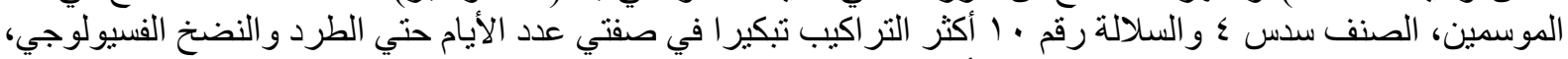

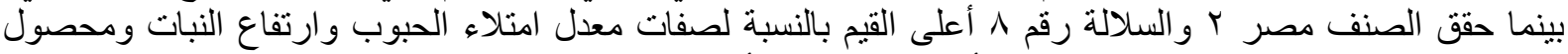

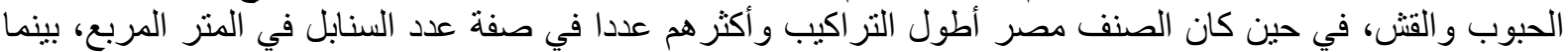

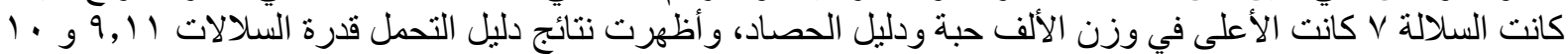

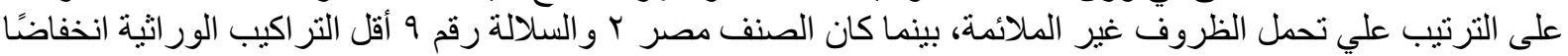

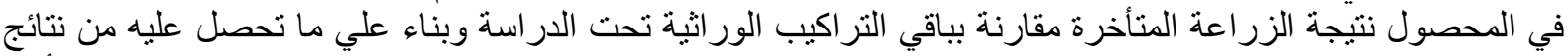

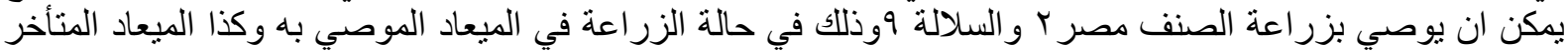
بمنطقة شمال الألتا. 